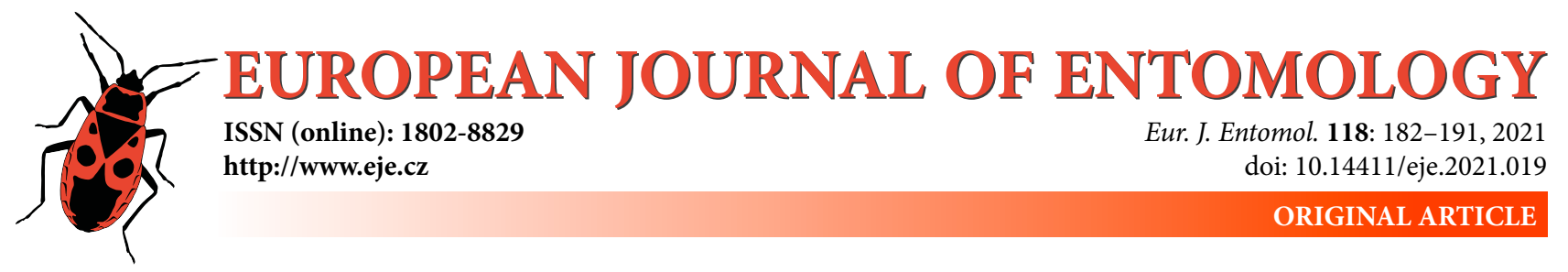

\title{
Assemblages of flower-visiting insects in clear-cuts are rich and dynamic
}

\author{
Per MILbERg iD, Victor ERIKSSON DiD and KarL-Olof BERGMAN iD \\ IFM Biology, Conservation Ecology Group, Linköping University, 58183 Linköping, Sweden; e-mails: per.milberg@liu.se, \\ v.eriksson89@gmail.com, karl-olof.bergman@liu.se
}

Key words. Syrphidae, Apoidea, Lepturinae, colour pan trap, flower abundance

\begin{abstract}
Clear-cuts in production forests provide an open, sunny environment, with an abundance of nectar, as well as exposed soil and woody debris. This makes them a potential habitat for several groups of insects that typically use open habitats like grassland, including those species that visit flowers. In the current study, we used colour pan traps to catch flower-visiting species. Study sites were selected according to age (2-8 yrs since clear-cut) and land-use history (forest or meadow 150 yrs ago). We caught and identified solitary bees (395 specimens belonging to 59 species), social bees (831/16), other Hymenoptera (367/66), Syrphidae (256/31), and beetles (Lepturinae \& Cetoniinae; 11,409/12). Age of the clear-cut strongly affected species composition as well as several groups and species, with most species caught mainly in the younger clear-cuts. Flower abundance statistically affected several groups and species, but inferring causation is difficult due to the flower-richness bias in pan trap catches. Bare soil and woody debris were important for the insect assemblage sampled, while bare rock was not. Although the majority of the insects caught were forest species, about one third of the species were associated with open, agricultural sites and hence seem to be able to locate and exploit resources in clear-cuts.
\end{abstract}

\section{INTRODUCTION}

Production forests cover vast tracts of land and are habitats for many organisms. When production systems are based on native vegetation they may support a large proportion of native fauna and flora (Bergner et al., 2015; Hanula et al., 2016; Rivers et al., 2018) and since the areas affected are large, potential habitats that may be created by forestry practices are important for understanding population dynamics of species at the landscape scale (Bergman et al., 2018).

Today, many production forests are subject to clear-cutting, i.e. all or most trees in an area are removed. Hence, in the otherwise dark sub-canopy environment, there is a brief period of openness and exposure to sun. After a clearcut operation, there is great change in the vegetation involving both mortality and establishment of new genets (Bergstedt \& Milberg 2001, 2008; Palviainen et al., 2005) as well as an increase in the biomass and flowering of sub-canopy species (Bergstedt et al., 2008; Milberg et al., 2019). At the same time, other species exploit these open environments, such as butterflies (Berg et al., 2011; Blixt et al., 2015; Korpela et al., 2015; Viljur \& Teder, 2016, 2018; Ohwaki et al., 2018; Bergman et al., 2020) and birds (Żmihorski et al., 2016; Ram et al., 2020). Other insect groups that exploit clear-cuts include bees and wasps (Fye, 1972; Cartar, 2005; Romey et al., 2007; Pengelly \& Cartar,
2010; Rubene et al., 2015; Westerfelt et al., 2015, 2018; Heneberg et al., 2016; Roberts et al., 2017; Johansson et al., 2020), hoverflies (Makino et al., 2006; Deans et al., 2007; Berglund \& Milberg, 2019; Johansson et al., 2020), and flower-visiting beetles (Makino et al., 2006; Berglund $\&$ Milberg, 2019). Compared with mature forests, there are more pollinators in clear-cuts (Nielsen \& Totland, 2014) and higher densities of bees and hoverflies (e.g. Makino et al., 2006; Deans et al., 2007; Romey et al., 2007; Proctor et al., 2012; Roberts et al., 2017; Rodríguez \& Kouki, 2017; Amos, 2019).

Understanding the processes that determine the presence and abundance of flower-visiting insects in production forests can help us maintain pollination services (Hanula et al., 2016; Rivers et al., 2018; Gómez-Martínez et al., 2020; Krishnan et al., 2020). For many flower-visiting insects, other plant or animal resources are needed in addition to nectar and pollen. Flower abundance is therefore only one of several potentially important factors determining the occurrence of species in clear-cuts. For example, the exposed soil that is created by preparing the site for sowing or planting may create nest sites for some species of solitary bees (Armbruster \& Guinn, 1989; Heneberg et al., 2016; Rodríguez \& Kouki, 2017; Proesmans et al., 2019) and some species can benefit from the warm micro-climate (Potts \& Willmer, 1997; Potts et al., 2005), a feature that in Sweden 
is enhanced by exposed bedrock. The sudden addition of large amounts of dead wood, especially fine woody debris, is also typical of clear cuts. These can be used as nesting sites by some solitary bees (Westerfelt et al., 2015, 2018; Rodríguez \& Kouki, 2017).

Conditions and resources change quickly in clear-cuts, which is likely to affect resident insect assemblages. For example, fine woody debris decomposes, exposed soil becomes overgrown, hostplant biomass may increase, and the abundance or diversity of parasitic species can change, particularly if there is a temporal delay in tracking host species that exploit clear-cuts. Another factor that is likely to influence the assemblages is the time it takes for a species to "find" a potential site and increase in abundance.

The aim of the present study was to relate the abundance of insects attracted to flowers, to:

(i) the age of the clear-cut, where we expect responses due to changes in a resource or a delay in dispersal and/or population build-up;

(ii) flower abundance, which is known to affect butterflies (Ibbe et al., 2011) and burnet moths (Bergman et al., 2020);

(iii) woody debris, that can provide nest sites for some species;

(iv) exposed mineral soil, which some species need for nesting;

(v) exposed bedrock, which can affect the micro-climate by retaining heat (warmer and longer season).

The above were evaluated by grouping the number of insects caught in different ways, and considering both the number of species and number of specimens. Data were grouped according to: Superfamily; Feeding style [herbivore, carnivore, saprophage, detritivore or parasite (parasite, parasitoid, cleptoparasite)]; and Preferred habitat (forest or open agricultural land).

Insects were caught using colour pan traps, a method designed for flower-visiting insects and often recommended because of its selectivity (compared with passive traps) and ability to trap over a long period of time (compared with netting). Like all methods of catching insects, it involves some bias, most notably involving flower abundance (Baum \& Wallen, 2011; Saunders \& Luck, 2013; Templ et al., 2019; Westerberg et al., 2021). The taxa studied were (i) social Apoidea, (ii) solitary Apoidea, (iii) "other Hymenoptera" (Pompilidae, Tiphiidae, Chrysidoidea), (iv) Lepturinae, (v) Cetoniinae and (vi) Syrphidae.

\section{MATERIAL AND METHODS}

\section{Sites studied}

The sites studied were in Östergötland, southern Sweden, in a landscape consisting mainly of coniferous forest intermixed with lakes, bogs, small patches of seminatural grassland and arable fields. The sites consisted of 48 forest patches that had been clear-cut, ranging from 1.5 to 6.6 ha in size. They were all $>300$ $\mathrm{m}$ from the nearest seminatural grassland and $>300 \mathrm{~m}$ from the nearest clear-cut. As the first years after clear-cutting are the most dynamic, we selected sites that were cut between 2 and 8 years previously.
Half of the clear-cuts were meadows in the 1870s and the other half were coniferous forest. The land-use information was extracted from historical cadastral maps (Häradsekonomiska kar$\tan$ ) for Östergötland produced between 1868 and 1877 (Janson, 1993; Runborg, 1994). Since the 1870s, at least one generation of conifer-dominated forest was grown on these sites; rotations are between 70 and 140 years in this region (Ibbe et al., 2011). Previous studies at the same sites have shown that those that were previously meadows have a higher abundance of herbaceous plants than those that were previously forests (Jonason et al., 2014, 2016). By selecting clear-cuts with different land-use histories, we assumed our sampling would include sites with a range of flower abundances.

Apart from history and age, we tried to select clear-cuts that were as similar as possible in terms of productivity, and were previously dominated by conifers (i.e. Picea abies and Pinus sylvestris). In our study system, soil disturbance occurs accidentally during harvest and timber extraction, while patches of bare soil are created when preparing for planting. Traditionally, woody debris is left in clear-cuts, but recently the practice of extracting it for use as biofuel has increased in southern Sweden.

\section{Vegetation sampling}

Vegetation in the 48 clear-cuts was sampled in August to early October 2013. One-hundred circular plots (radius $1 \mathrm{~m}$ ) were evenly distributed over each clear-cut along straight transects placed $25 \mathrm{~m}$ apart. In each plot, presence/absence was recorded for vascular plant species. For each clear-cut, a species' frequency was calculated as the number of plots in which it was present (see Jonason et al., 2014 for details). In the present study, we used the sum of the frequencies of those species that have flowers visited by insects, hence forth called "flower index" (Table 1). As expected, this index differed depending on land-use history, with those sites that were historically meadow supporting a higher frequency of species with flowers that attract insects (difference in means was 199 with $\mathrm{CI}_{95 \%} 80 ; 317$ ).

For every third plot sampled, we also recorded the identity of the species and the diameter of stumps, snags and living trees $>10$ $\mathrm{cm}$ in diameter within an area of $100 \mathrm{~m}^{2}$ (a circle with a radius of $5.64 \mathrm{~m}$ ). These values were used to calculate basal area at stump height in order to obtain an estimate of the composition and density of the forest before clear-cutting. In addition, within the same plots, the presence of bare mineral soil, bare rock, and logging residues were recorded. These data were converted to $\ln$ (odds) of encountering any of these three in a clear-cut [odds $=($ number of plots where present +0.5$)$ / (number of plots where absent +0.5$)$ ].

\section{Pan trapping of insects}

The pans used to collect insects were painted with either blue, white or yellow UV-reflecting paint (Soppec, Sylva mark fluo marker, Nersac, France). The pans had a diameter of $8.7 \mathrm{~cm}$, a volume of $0.5 \mathrm{~L}$, and were filled with nontoxic propylene glycol $(40 \%$ concentration), to decrease surface tension and act as

Table 1. Characteristics of the clear-cuts sampled $(N=48)$ in July.

\begin{tabular}{lcccc}
\hline & Average & SD & Min & Max \\
\hline Age (year) & 4.9 & 2.2 & 2.0 & 8.0 \\
Flower index $^{1}$ & 677 & 225 & 330 & 1399 \\
Odds of bare soil in plot $^{2}$ & 0.61 & 1.43 & 0.015 & 6.6 \\
Odds of bare rock in plot $^{2}$ & 12.3 & 19.8 & 0.28 & 67 \\
$\begin{array}{l}\text { Odds of woody debris in plot } \\
\text { Deciduous trees (\%, based }\end{array}$ & 10.0 & 18.1 & 0.33 & 67 \\
on basal area of stumps) & 2.5 & 2.5 & 0.0 & 8.4 \\
\hline
\end{tabular}

${ }^{1}$ Flower index is based on data recorded by Jonason et al. (2014).

${ }^{2} \ln$ (odds) was used in statistical analyses. 
a preservative. A small hole (4 $\mathrm{mm}$ in diameter) was drilled at the top of each bowl to ensure that rainwater could drain away. A pan trap triplet, i.e. three pans, one of each colour, was placed on a steel stake.

Three trap triplets were placed in each clear-cut at the same height as the vegetation and in places considered to be representative of the clear-cut (avoiding, e.g. wet patches, exposed bedrock, tracks). Traps were set for two one-week periods: in early and late July 2013. This corresponds to a trapping effort of 42 trap triplet days per clear-cut. The pans were covered with lids between the two collecting periods. Data were pooled across the two collecting periods and the trap triplets per clear-cut.

The following taxonomic groups were identified to species: Lepturinae, Cetoniinae, Apoidea, Vespoidea (Pompilidae, Tiphiidae), Chrysidoidea (Chrysididae 8 spp.) and Syrphidae. Other insects caught that are not considered here were Vespidae, various small Coleoptera and Lepidoptera. Of the Apoidea, social species (i.e. Apis and Bombus) tend to be more numerous and fly great distances during foraging. Therefore, we treated social and solitary Apoidea as two separate groups. Vespoidea (Pompilidae, Tiphiidae) and Chrysidoidea were grouped together and referred to as "other Hymenoptera".

\section{Statistical analyses}

Generalized Linear Models (GLM Poisson distribution, with adjustment for overdispersion; log link) of the numbers of specimens and species caught per clear-cut were produced using TIBCO Statistica 13 (www.tibco.com). Five explanatory variables were tested: (i) the age of the clear-cut, (ii) the flower index, (iii) the odds of finding bare soil, (iv) the odds of finding exposed bedrock, and (v) the odds of woody debris. Not unexpectedly, flower index, bare soil, bare rock and woody debris all decreased significantly with the age of the clear-cut, with the amount of woody debris correlating positively with the amount of both bare soil and bare rock. Hence, multiple regression, or model selection, was not appropriate and a number of simple regressions were instead conducted, with the outcomes compared based on their Z-values (the test statistic for a Wald test). As sample size was constant, we used $Z$-values to directly compare all the analyses (which would not be possible using regression coefficients). Models with high Z-values or low negative Z-values, depending on the direction of the relationship, indicate a strong association between the response variable and the explanatory variable in question.

These analyses were conducted on the number of species and specimens after data had been grouped based on taxonomy (Lepturinae, Cetoniinae, solitary Apoidea, social Apoidea, other Hymenoptera, Syrphidae). Furthermore, the number of species with different modes of feeding were analysed in a similar way (herbivores, carnivores, parasites [including kleptoparasites and parasitoids], decomposers; n.b. that some species can have more than one feeding style).

Species were assigned to "landscape type" using The Swedish Species Information Centre (www.artfakta.se). In this classification system, a species can be assigned to one or more of seven "landscape types". Adding further detail, species can be considered as "mainly" or "partly" associated with a certain type of landscape, and we re-coded these as 2 (mainly) and 1 (partly). We assigned a preferred habitat to species by subtracting the value for agricultural landscapes from forest landscapes, and called this difference a "forest affiliation value", ranging from +2 (only and "mainly" occurring in forest landscapes) to -2 (only and "mainly" occurring in agricultural landscapes). Averaging such association values for species caught in a clear-cut resulted in a "forest affilia- tion index". This index was used as the response in similar GLMs as described above (but choosing linear model and identity).

Corresponding analyses were also carried out on twenty-one species judged sufficiently abundant (minimum of 20 specimens) and widespread (minimum of 15 clear-cuts) for meaningful species-level analyses.

Finally, a Principal Component Analysis (PCA) was used to illustrate how species composition varied among the 48 clear-cuts. An advantage of PCA is that environmental variables can be passively added to the solution to assist interpretation. We used the five variables used in the above GLMs (age of clear-cut; flower index; odds of finding bare soil, exposed bedrock and woody debris in plots).

All data collected in the current study are available via Zenodo: https://doi.org/10.5281/zenodo.4756772.

\section{RESULTS}

In total 13,258 insects belonging to 184 species were identified. Lepturinae were the most numerous $(10,525$ specimens/10 taxa), followed by Cetoniinae (884/2), social Apoidea (831/16), solitary Apoidea (395/59), other Hymenoptera (367/66) and Syrphidae (256/31). The number of species and specimens per clear-cut varied substantially (Table 2).

Table 2. Average number (SD) of individuals and species caught per clear-cut. Each clear-cut had three pan trap triplets (three traps of three different colours) that were set for 2 weeks during July.

\begin{tabular}{lcc}
\hline & Specimens & Species \\
\hline Lepturinae & $219.3(139.75)$ & $4.8(0.93)$ \\
Cetoniinae & $18.4(14.13)$ & $1.9(0.31)$ \\
Solitary Apoidea & $8.2(4.95)$ & $5.7(2.77)$ \\
Social Apoidea & $17.3(11.72)$ & $4.5(1.58)$ \\
Other Hymenoptera & $7.6(3.82)$ & $5.7(2.60)$ \\
Syrphidae & $5.3(4.55)$ & $3.0(1.96)$ \\
\hline
\end{tabular}

\section{Regression analyses}

\section{The relative importance of the five explanatory variables}

Of the 38 models for each explanatory variable (Fig. 1), age of clear-cut, flower index, bare soil, and woody debris were all important $(13,11,13$ and 13 significant models, respectively). In three cases, there was an increase with age of clear-cut and in ten cases a decrease with age (Fig. 1a). There were four cases in which abundance increased with an increase in the flower index and, surprisingly, seven in which abundance decreased (Fig. 1b). There were eleven and ten cases (of 13) in which abundance increased with bare soil and woody debris, respectively (Fig. 1b). By contrast, bare rock had low explanatory power (2 significant models).

\section{Grouping according to taxonomy}

Of the 30 GLMs for the number of specimens, ten were significant: Lepturinae increased with the age of the clear cut and decreased with increased flower abundance (flower index), bare soil, and woody debris (Fig. 1). The number of specimens of solitary Apoidea and other Hymenoptera both decreased with clear-cut age (Fig. 1a), and increased with bare soil (Fig. 1c), and woody debris (Fig. 1e). 


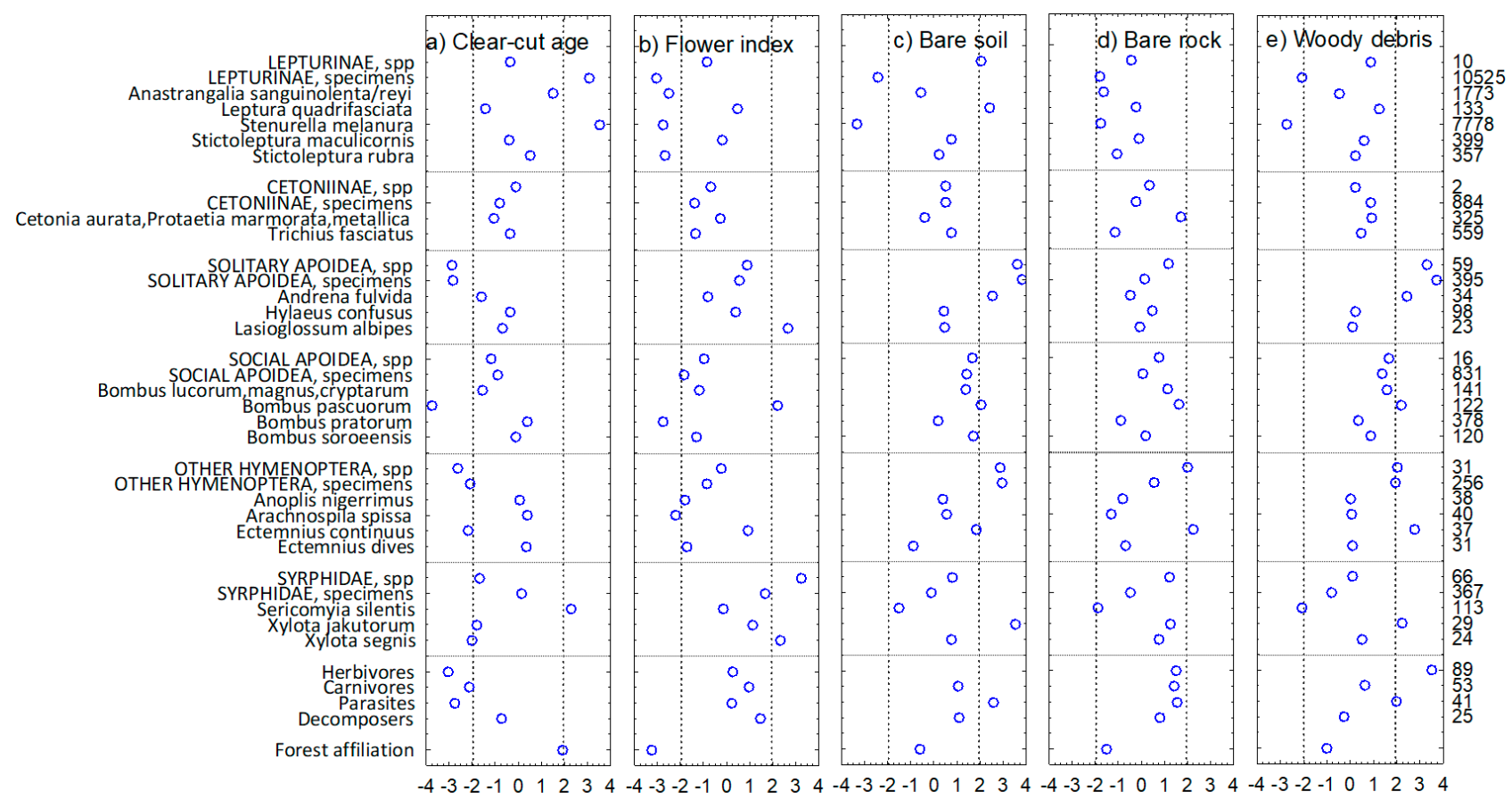

\section{Z-values}

Fig. 1. GLM outcomes in the form of Z-values for each of the five explanatory variables. Large positive values mean a positive relationship, and vice versa; Data points between the dotted lines were statistically non-significant. Numbers to the right are number of species or number of specimens.

The number of species of solitary Apoidea and other Hymenoptera both decreased with age and increased with bare soil and woody debris, whereas other Hymenoptera also increased with bare rock (Fig. 1). In addition, the number of species of Syrphidae increased with the flower index, and that of Lepturinae with bare soil.

\section{Grouping according to life-style}

The number of species of herbivores, carnivores, and parasites each decreased significantly with clear-cut age (Fig. 1a). Furthermore, herbivores and parasites increased with increasing amounts of bare soil (Fig. 1c) and woody debris (Fig. 1e).

\section{Grouping according to affiliation with forest vs agricultural land}

Lepturinae and Cetoniinae were mainly forest species whereas other taxa were represented by both forest species and open landscapes species (Fig. 2).

The average forest affiliation index decreased with increases in the flower index, i.e. the proportion of insect species whose main preference is for open landscapes increased with increasing abundances of insect-attracting flowers (Fig. 1b). In parallel, there was a tendency for the forest affiliation index to decrease with clear-cut age (Fig. 1a).

\section{Species-wise analyses}

Of the 21 species analysed, the abundances of 13 were significantly affected by one or more of the five explanatory variables (Fig. 1). The age of the clear-cut affected five species either negatively (one social Apoidea, one other
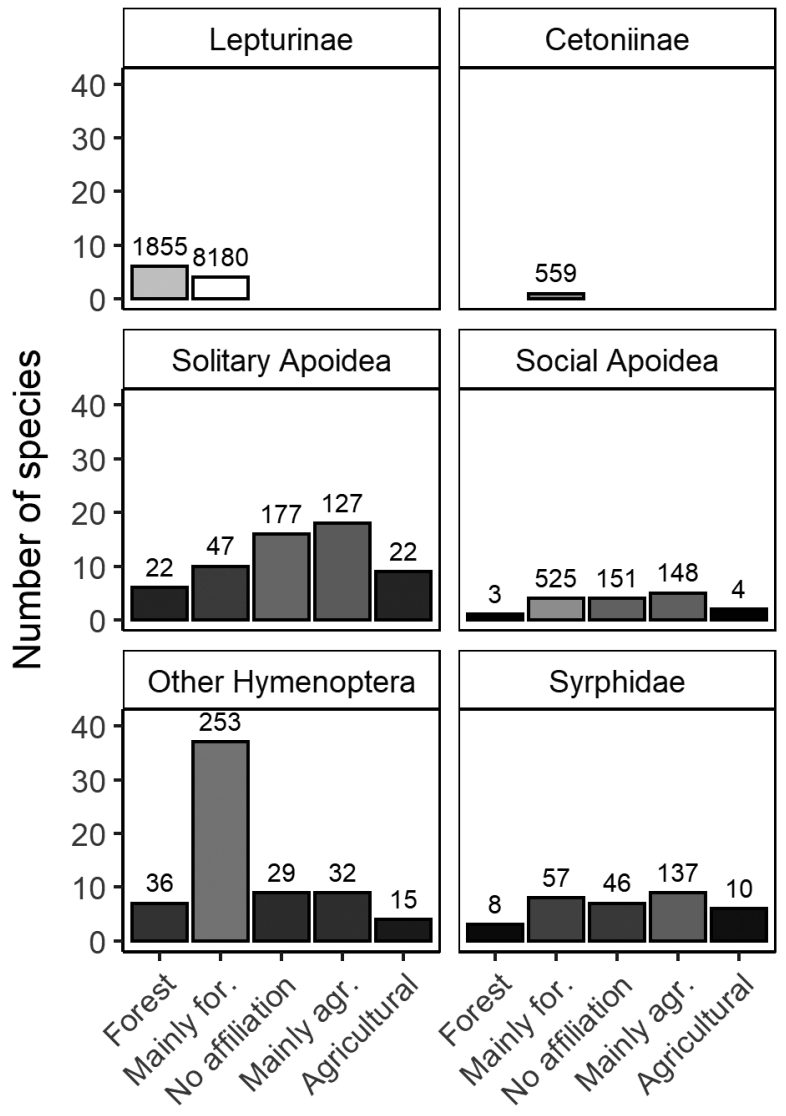

Fig. 2. Total number of species per forest affiliation value. The number above the bar is the number of specimens caught. 

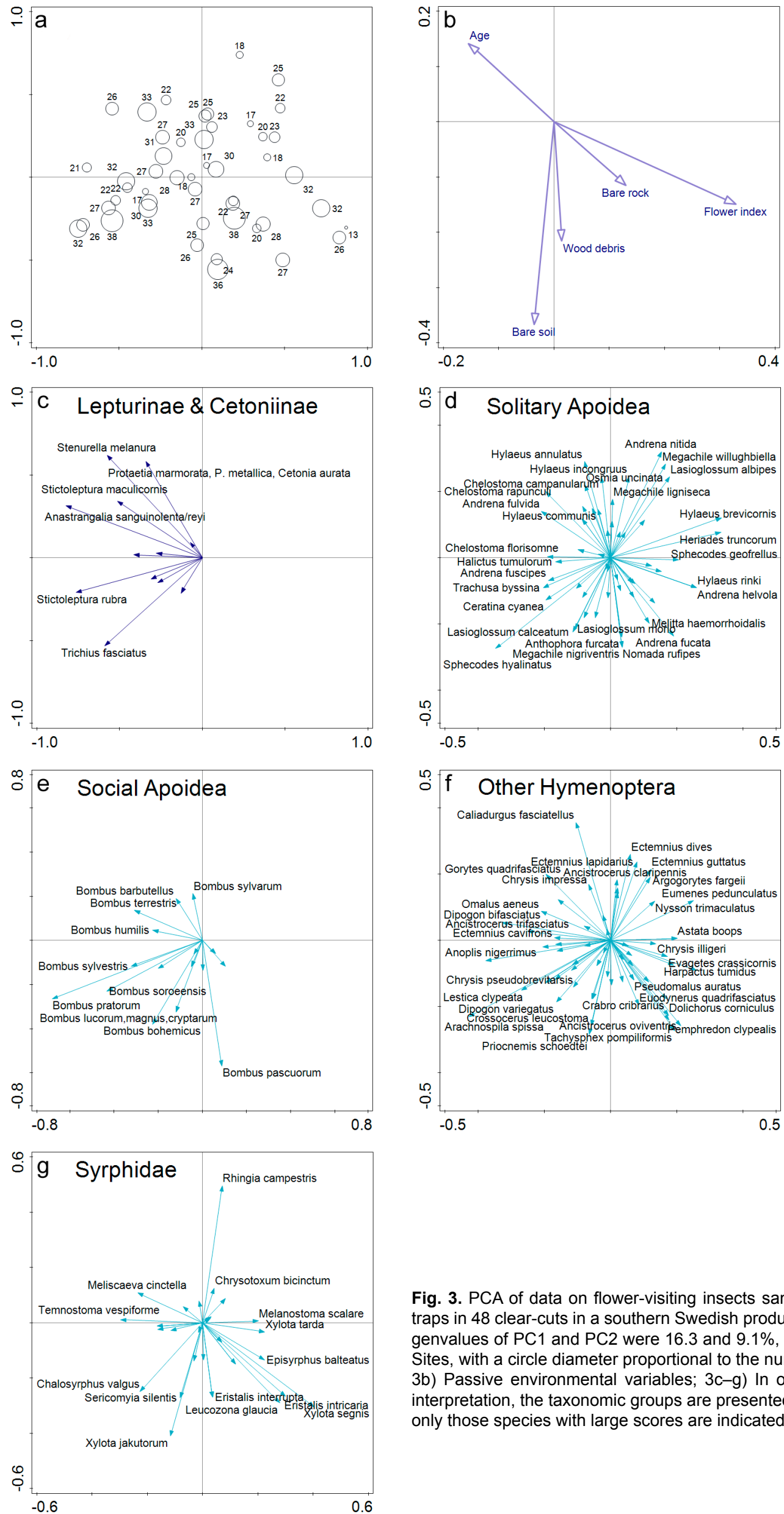

Fig. 3. PCA of data on flower-visiting insects sampled using pan traps in 48 clear-cuts in a southern Swedish production forests. Eigenvalues of PC1 and PC2 were 16.3 and $9.1 \%$, respectively. 3a) Sites, with a circle diameter proportional to the number of species; 3b) Passive environmental variables; $3 \mathrm{c}-\mathrm{g}$ ) In order to facilitate interpretation, the taxonomic groups are presented separately and only those species with large scores are indicated by name. 
Hymenoptera, one Syrphidae) or positively (one Lepturine, one Syrphid; Fig. 1a).

The flower index significantly affected eight species either negatively (three Lepturinae, one social Apoidea, one other Hymenopteran) or positively (one solitary Apoidea, one social Apoidea, one Syrphid; Fig. 1b).

Four species were positively affected by bare soil (one Lepturinae, one solitary and one social Apoidea, one Syrphidae) and one negatively (one Lepturinae; Fig. 1c). One species was positively affected by bare rock (other Hymenoptera; Fig. 1d). Finally, four species were positively affected by woody debris (one solitary and one social Apoidea, one other Hymenoptera, one Syrphidae) and two negatively (one Lepturinae, one Syrphidae; Fig. 1e).

\section{PCA}

The multivariate analyses not unexpectedly confirmed the above results in the sense that clear-cut age and flower index were the factors that best correlated with PC1, while bare soil and woody debris aligned with PC2 (Fig. 3b). Lepturinae were mainly associated with older clear-cuts (Fig. 3c) while several species of other Hymenoptera (Fig. 3f) and Syrphidae (Fig. 3g) preferred young clear-cuts. The presence of both solitary and social Apoidea was not associated with the age-gradient, as few, if any, species had arrows coinciding with this gradient (Fig. 3d, e).

\section{DISCUSSION}

\section{Clear-cuts as habitat for flower-visiting insects}

We recorded a species-rich assemblage of flower-visiting insects in clear-cuts, with more than 13,000 specimens from 184 species collected. This adds to the growing evidence that numerous pollinator species occur in clear-cuts (Blixt et al., 2015; Rubene et al., 2015; Bergman et al., 2020; Johansson et al., 2020). It is difficult to compare species numbers recorded in different studies because the sampling methods used and sampling effort differs. So, we compared our results only with studies using pan traps (sometimes combined with other methods of sampling), with similar sampling effort, and geographical coverage as in our study. We identified three previous, comparable studies on clear-cuts in Fennoscandia. Johansson et al. (2020), using a similar sampling effort to the current study, recorded 61 species of bees (Apoidea) compared with our 75 species, while Rubene et al. (2015), with approximately twice our sampling effort, recorded 100 species. Rodríguez $\&$ Kouki (2017) recorded only 22 species, but with only a third of our sampling effort.

Our abundances of bees were similar to Rubene's, using the same type of pan traps: 4.3 and 3.7 specimens per trap triplet per week, respectively, whereas Rodríguez's are lower (1.4). In the latter study, samples were also collected early in the season when few Apoidea and especially Bombus were caught. They therefore likely underestimated bee densities compared with the current study and that of Rubene et al. (2015). The percentage of social Apoidea specimens (i.e. Bombus spp. and honeybees) among all of the Apoidea individuals collected were also similar: $68 \%$,
$62 \%$ and $62 \%$ in our study, Rubene et al. (2015) and Rodriguez \& Kouki (2017), respectively. Hence, the patterns seem surprisingly consistent throughout the boreal and boreonemoal zones in Fennoscandia.

Compared with clear-cuts in European boreal forests, bee density was about four times higher in deciduous forest in eastern North America, according to two studies. Romey et al. (2007) sampled a single clear-cut (2.0 ha) and recorded 14.9 bees per week per trap triplet, of which 5.7\% were social Apoidea. A complication is that traps were only set for $6 \mathrm{~h}$ per day, resulting in an underestimation of numbers compared to the above studies. Roberts et al. (2017) recorded 18.6 bees per week per trap triplet, of which social species made up just $2 \%$ of individual bees (clearings ranging in size from 0.08 to 1.29 ha). However, insects in that study were only sampled on warm, sunny days, which will have resulted in an overestimation compared with that recorded in the aforementioned boreal forest studies.

Compared with grasslands, the numbers of flower-visiting insects recorded in clear-cuts were high. For example, Meyer et al. (2017) collected 67 species/993 specimens of bees, and 42/505 hoverflies from Alpine meadows using sweep netting and pan trapping. We recorded similar numbers using pan traps ( $75 / 1226$ bees and $31 / 256$ hoverflies). In a pan trapping study of insects in grasslands in Wales, Lucas et al. (2017) record 42/1171 hoverflies, and in Eire, Power et al. (2016) record 34/1176 hoverflies using pan traps and transect walks. Despite longer sampling seasons, using two types of sampling and catching many more specimens, these two studies did not catch considerably more species of hoverflies than that recorded in clear-cuts in the present study.

Given that clear-cuts are a new phenomenon in boreal forests, it might be worthwhile speculating on the evolutionary history of the species that exploit them. Within boreal and boreonemoral forest, fire was an important disturbance factor (Bogusch et al., 2015) that occasionally killed trees and allowed the ground flora to flourish. Burnt and unburnt clear-cuts, however, differed in species composition, especially that of bees and wasps (Johansson et al., 2020). Some species might have adapted to exploit the open and sun-lit environments created by now-extinct mega-herbivores (Vera, 2000; Svenning, 2002; van Vuure, 2005; Ohwaki, 2018).

\section{A combination of species from forest and agricultural landscapes}

The assemblages we recorded consisted of both forest species and species considered to prefer agricultural landscapes. Of our 184 species, 62 were considered to be mainly $(\mathrm{N}=41)$ or only (21) associated with agricultural landscapes. This indicates we sampled a neglected habitat for these species (i.e. the landscape classifications for these species are wrong). Alternatively, these species were only occasional visitors to the forest environment we sampled. As many of the species have a relatively limited dispersal ability (Zurbuchen et al., 2010; Wright et al., 2015) and only social bees regularly forage over long distances (Greenleaf et al., 2007; Osborne et al., 2008), we favour 
the first explanation. If so, our study indicates that clearcuts constitute a hitherto neglected, open, sunlit habitat for many species normally considered grassland specialists (cf Berg et al., 2011; Ibbe et al., 2011; Viljur \& Teder 2016; Ohwaki et al., 2018; Bergman et al., 2020). Given that clear-cuts are likely to remain an important forestry method over large areas of temperate and boreal forests, this land will continue to support pollinator abundance and diversity in these landscapes (Bergman et al., 2008, 2018).

Forest species, like many Lepturinae, presumably dispersed over relatively short distances from adjacent forest to reach the clear-cuts we sampled, while many open-area species presumably dispersed over much longer distances from other open habitats. This could result in their later arrival at our sites, which would be reflected in a decrease in our forest affiliation index over time as more open-area species arrive. However, this assumption was not confirmed, and instead there was a tendency for the reverse pattern, i.e. that the proportion of open-area species decreased over time. Dispersal limitation therefore does not seem to be important in our study system.

\section{Short-term dynamics in clear-cuts}

Despite including only 2-8-year-old clear-cuts, our study clearly shows that short-term dynamics in insect abundance can be marked. One taxonomic group (solitary Apoidea) and three species (Bombus pascuorum/social Apoidea; Ectemnius continuus/other Hymenoptera; Xylota segnis/ Syrphidae) clearly decreased in abundance with clear-cut age. Furthermore, when grouping species according to mode of feeding, the frequency of herbivores, carnivores and parasites all decreased with clear-cut age, suggesting that there was a concomitant decrease in some fundamental resources. That parasite abundances clearly decreased was somewhat surprising as one would expect their abundances to lag behind that of their host species. However, any such lag would likely be only a single season, which may not be long enough to affect the broader patterns.

On the other hand, one group (Lepturinae) and two species (Stenurella melanura/Lepturinae; Sericomyia silentis/ Syrphidae) increased with clear-cut age (n.b. Stenurella melanura made up $74 \%$ of the Lepturinae). Increases in the abundances of Stenurella melanura and Lepturinae were expected as these species rely on dead wood and many lepturines have larval periods of 2-3 years (Ehnström \& Holmer, 2007) suggesting a delay in population build-up following harvesting and the immediate deposition of vast amounts of deadwood (stumps and fine woody debris).

The short-term dynamics in clear-cuts seem to be mainly caused by decreases in available resources. These changes did not affect all species on clear-cuts however, since both the composition of the vegetation (Jonason et al., 2016) and butterfly assemblages (Blixt et al., 2015) were relatively stable over the same time span.

\section{Flower index}

As previously shown, clear-cuts with a meadow history have a richer flora than those with a forest history (Jonason et al., 2016) and we expected a gradient in insect compo- sition that coincided with a gradient in the flower index. Such patterns exist for butterflies (Ibbe et al., 2011), burnet moths (Bergman et al., 2020) and bees (Fye, 1972), which all increase with flower abundance in clear-cuts. Furthermore, social Apoidea should have peaked in abundance when we sampled, and their many workers are known to make long foraging trips (Greenleaf et al., 2007; Osborne et al., 2008). They are therefore likely to accumulate in substantial numbers at sites where there is high production of nectar or pollen, thereby strengthening their abundance/flowering relationships compared with that of other groups. However, only one taxonomic group (Syrphidae) of six, and three species of 21, increased with the flower index. Furthermore, one taxonomic group (Lepturinae) and five species actually displayed a negative relationship with flower index. We propose three reasons for these unexpected results. First, estimating flower abundance is difficult, so the index we used (the total frequency of species with insect-attracting flowers) might be poorly related to the quantity of nectar and pollen available. Second, clearcut age had very strong explanatory power in this study and was negatively correlated with the flower index. Hence, the age factor might obscure a flower/abundance relationship. Third, catches in pan traps can suffer from a negative bias as flower abundance increases (Wilson et al., 2008; Baum \& Wallen, 2011; Templ et al., 2019; Westerberg et al., 2021), i.e. the likelihood of a catch decreases when there are more flowers in the vicinity of a trap. Positive relationships between pan trap catches and flowers therefore occur despite this potential negative bias and the effect of clearcut age. On the other hand, we believe that negative relationships are potentially erroneous when based on pan trap catches, and should therefore be treated with scepticism.

In addition to the total number of syrphid species, there were three species with significant, positive relationships between the flower index and abundance: Xylota segnis (Syrphidae), Bombus pascuorum: (social Apoidea) and Lasioglossum albipes (solitary Apoidea). There is nothing noteworthy in the biology of these species that could account for this (Bartsch et al., 2009; Falk, 2015). Both $X y$ lota segnis and Bombus pascuorum decreased significantly with age of the clear-cut and as age and flower index are negatively correlated, it is possible that their abundances were driven by some other feature of clear-cut age rather than flower abundance per se.

\section{Bare soil, bare rock and woody debris}

We assumed that the occurrence of exposed mineral soil and woody debris would be important for some species in the two most species-rich groups (solitary Apoidea and other Hymenoptera) as they require these resources for nesting (e.g. Grundel et al., 2010; Rubene et al., 2015; Heneberg et al., 2016; Rodríguez \& Kouki, 2017; Westerfelt et al., 2018; Proesmans et al., 2019). Our results showed that bare soil and woody debris in plots both had high explanatory power (11 and 10 positive and significant relationships to bare soil and woody debris, respectively). When selecting only those species that need bare soil or woody resources for nesting, there were also clear positive 
and significant relationships (data not shown). It is noteworthy that these patterns are so clear given that there was plenty of bare soil and woody debris in all of the clear-cuts. This suggests that the quantity of bare soil and woody debris are important factors shaping the assemblages of these insects. In addition, there might be quality issues regarding the existing woody debris that contributes to shaping these assemblages (e.g., Hilszczański et al., 2005; Stenbacka et al., 2010). For example, two species of wood-living Hymenopteran parasitoids were more abundant in clear-cuts than in two types of forest, while the opposite was reported for a third species (Stenbacka et al., 2010).

There were four species whose abundances significantly increased with increasing amounts of bare soil and four that increased with increasing amounts of woody debris (in total five species responded to one or both of these resources). The strong correlations between bare soil, woody debris and clear-cut age makes it difficult to separate the causal factors, but two of the five species nest in bare soil (Andrena fulvida, Ectemnius continuus) and two have larvae that live under bark (Leptura quadrifasciata, Xylota jakutorum). The fifth species, the generalist bumblebee Bombus pascuorum, has no apparent reason to track bare soil or dead wood, so we cannot yet speculate as to why it declines strongly in abundance with clear-cut age.

Finally, the abundance of one species (Ectemnius contin$u u s$ ) was positively associated with the amount of exposed rock. As the rock itself is not exploited by this species, this observation could either reflect differences in vegetation or soil conditions when soil cover is thin (often the case near bare rock), or it may simply be a consequence of a more advantageous microclimate near sun-exposed bedrock (warmer and longer season, e.g. Proctor et al., 2012). Whether bare rock in itself attracts insects or simply makes nearby spots warmer and more attractive, remains to be resolved.

Overall, the amounts of bare soil and woody debris found in clear-cuts was important for determining the assemblage of flower-visiting insects, while the amount of bare rock had little effect.

\section{CONCLUSIONS}

- Clear-cuts in productions forests are exploited by a large number of flower-visiting species.

- Although the majority of specimens recorded were forest species, many were associated with open, agricultural sites that seem to move in to exploit similar resources in clear-cuts.

- The dynamics of the assemblages are strong in the first decade after the clear-cut with the majority of species decreasing in abundance over time.

- Flower abundance had surprisingly small explanatory power, which is likely to be partly dependent on the rapid decrease in flower abundance over time and the potential for a negative bias when using pan traps.

- Bare soil and woody debris were important for the insect assemblage sampled, while bare rock was not.
ACKNOWLEDGEMENTS. Skogssällskapet provided financial support (project no. 1213-108/159-9). D. Jonason and T. Blixt assisted with the field work and L. Norén (Apoidea, Vespoidea), H.L. Berglund (Syrphidae) and T. Germain (Lepturinae) with identification. A. Larsson (SLU) assisted with obtaining background data on the species.

\section{REFERENCES}

Amos J.J.H. 2019: Habitat Use in Undisturbed Forest and the Effect of Variable Retention Harvesting on Pollinator Assemblages (Apoidea, Syrphidae) in the Boreal Forest of Alberta. MSc thesis, Forest Biology and Management, Department of Renewable Resources, University of Alberta, $121 \mathrm{pp}$.

Armbruster W.S. \& GuinN D.A. 1989: The solitary bee fauna (Hymenoptera: Apoidea) of interior and Arctic Alaska: flower associations, habitat use, and phenology. - J. Kans. Entomol. Soc. 62: 468-483.

Bartsch H., Binkiewicz E., Klintbuer A., RÅdén A. \& Nasibov E. 2009: Encyclopedia of the Swedish Flora and Fauna. Diptera: Syrphidae: Eristalinae \& Microdontinae. ArtDatabanken, SLU, Uppsala [in Swedish].

BAUM K.A. \& WALLEN K.E. 2011: Potential bias in pan trapping as a function of floral abundance. - J. Kans. Entomol. Soc. 84: $155-159$.

Berg Å., Ahrné K., Öckinger E., Svensson R. \& SöDerström B. 2011: Butterfly distribution and abundance is affected by variation in the Swedish forest-farmland landscape. - Biol. Conserv. 144: 2819-2831.

Berglund H.-L. \& Milberg P. 2019: Sampling of flower-visiting insects: Poor correspondence between the catches of colour pan-trap and sweep netting. - Eur. J. Entomol. 116: 425-431.

Bergman K.-O., Dániel Ferreira J., Milberg P., Öckinger E. \& WESTERBERG L. 2018: Landscape mediated patterns of butterfly occurrence in semi-natural grasslands. - Landsc. Ecol. 33: 2189-2204.

Bergman K.-O., Burman J., Jonason D., Larsson M., Ryrholm N., Westerberg L. \& Milberg P. 2020: Clear-cuts are temporary habitats, not matrix, for endangered grassland burnet moths (Zygaena spp.). - J. Insect Conserv. 24: 269-277.

Bergner A., Avci M., Eryiğit H., Jansson N., Niklasson M., Westerberg L. \& Milberg P. 2015: Influences of forest type and habitat structure on bird assemblages of oak (Quercus spp.) and pine (Pinus spp.) stands in southwestern Turkey. - For. Ecol. Manag. 336: 137-147.

Bergstedt J. \& Milberg P. 2001: The impact of logging intensity on field-layer vegetation in Swedish boreal forests. - For. Ecol. Manag. 154: 105-115.

Bergstedt J. \& Milberg P. 2008: The impact of logging on species richness and turnover of field layer species in Swedish boreal forests. - Open Environ. Biol. Monit. J. 1: 48-57.

Bergstedt J., Hagner M. \& Milberg P. 2008: Effects on vegetation composition of a modified forest harvesting and propagation method compared with clear-cutting, scarification and planting. - Appl. Veg. Sci. 11: 159-168.

Blixt T., Bergman K.-O., Milberg P., Westerberg L. \& Jonason D. 2015: Clear-cuts in production forests are not matrix, but neo-habitats for butterflies. - Acta Oecol. 69: 71-77.

Bogusch P., Blažej L., Trýzna M. \& Heneberg P. 2015: Forgotten role of fires in Central European forests: critical importance of early post-fire successional stages for bees and wasps (Hymenoptera: Aculeata). - Eur. J. For. Res. 134: 153-166.

CARTAR R.V. 2005: Short-term effects of boreal forest logging disturbance on bumble bees, bumble beepollinated flowers, and the bee-flower match. - Biodiv. Conserv. 14: 1895-1907. 
Deans A.M., Smith S.M., Malcolm J.R., Crins W.J. \& Belloce M.I. 2007: Hoverfly (Syrphidae) communities respond to varying structural retention after harvesting in Canadian peatland black spruce forests. - Environ. Entomol. 36: 308-318.

Ehnström B. \& Holmer M. 2007: Encyclopedia of the Swedish Flora and Fauna. Coleoptera: Cerambycidae. ArtDatabanken, SLU, Uppsala [in Swedish].

FALK S. 2015: Field Guide to the Bees of Great Britain and Ireland. Bloomsbury, London, $432 \mathrm{pp}$.

FYE R.E. 1972: The effect of forest disturbances on populations of wasps and bees in northwestern Ontario (Hymenoptera: Aculeata). - Can. Entomol. 104: 1623-1633.

Gómez-Martínez C., Aase A.L.T.O., Totland Ø., Rodríguez-Pérez J., Birkemoe T., Sverdrup-Thygeson A. \& LÁzaro A. 2020 Forest fragmentation modifies the composition of bumblebee communities and modulates their trophic and competitive interactions for pollination. - Sci. Rep. 10: 10872, $16 \mathrm{pp.}$

Greenleaf S.S., Williams N.M., Winfree R. \& Kremen C. 2007: Bee foraging ranges and their relationship to body size. - Oecologia 153: 589-596.

Grundel R., Jean R.P., Frohnapple K.J., Glowacki G.A., Scott P.E. \& PAVLovic N.B. 2010: Floral and nesting resources, habitat structure, and fire influence bee distribution across an openforest gradient. - Ecol. Appl. 20: 1678-1692.

Hanula J.L., Ulyshen M.D. \& Horn S. 2016: Conserving pollinators in North American forests: a review. - Nat. Areas $J$. 36: $427-439$.

Heneberg P., Bogusch P. \& ŘezÁč M. 2016: Off-road motorcycle circuits support long-term persistence of bees and wasps (Hymenoptera: Aculeata) of open landscape at newly formed refugia within otherwise afforested temperate landscape. - Ecol. Engin. 93: 187-198.

Hilszczański J., Gibb H., Huältén J., Atlegrim O., Johansson T., Pettersson R.B., Ball J.P. \& Danell K. 2005: Parasitoids (Hymenoptera, Ichneumonoidea) of saproxylic beetles are affected by forest successional stage and dead wood characteristics in boreal spruce forest. - Biol. Conserv. 126: 456-464.

Ibbe M., Milberg P., Tunér A. \& Bergman K.O. 2011: History matters: Impact of historical land use on butterfly diversity in clear-cuts in a boreal landscape. - For. Ecol. Manag. 261: 1885-1891.

JANSSON U. 1993: Cadastral Maps 1800-1934. The Swedish National Heritage Board. Almqvist \& Wiksell Tryckeri, Uppsala, 76 pp. [in Swedish].

Johansson V., Gustafsson L., Andersson P. \& Hylander K. 2020: Fewer butterflies and a different composition of bees, wasps and hoverflies on recently burned compared to unburned clear-cuts, regardless of burn severity. - For. Ecol. Manag. 463: $118033,15 \mathrm{pp}$.

Jonason D., Ibbe M., Milberg P., Tunér A., Westerberg L. \& Bergman K.O. 2014: Vegetation in clear-cuts depends on previous land use: a century-old grassland legacy. - Ecol. Evol. 4: 4287-4295.

Jonason D., Bergman K.-O., Westerberg L. \& Milberg P. 2016: Land-use history exerts long-term effects on the flora in clearcuts. - Appl. Veget. Sci. 19: 634-643.

Korpela E.-L., HyvöNen T. \& KuUSAari M. 2015: Logging in boreal field-forest ecotones promotes flower-visiting insect diversity and modifies insect community composition. - Insect Conserv. Divers. 8: 152-162.

Krishnan S., Wiederkehr Guerra G., Bertrand D., WertzKanounnikoff S. \& Kettle C.J. 2020: The Pollination Services of Forests: A Review of Forest and Landscape Interventions to Enhance their Cross-sectoral Benefits. Forestry Working Paper No. 15. FAO \& Bioversity International, Rome, 81 pp.
Lucas A., Bull J.C., De Vere N., Neyland P.J. \& Forman D.W. 2017: Flower resource and land management drives hoverfly communities and bee abundance in seminatural and agricultural grasslands. - Ecol. Evol. 7: 8073-8086.

Makino S., Goto H., Inoue T., Sueyoshi M., Okabe K., Hasegawa M., Hamaguchi K., Tanaka H. \& OKochi I. 2006: The monitoring of insects to maintain biodiversity in Ogawa forest reserve. - Environ. Monitor. Assess. 120: 477-485.

Meyer S., Unternährer D., Arlettaz R., Humbert J.Y. \& Menz M.H. 2017: Promoting diverse communities of wild bees and hoverflies requires a landscape approach to managing meadows. - Agric. Ecosyst. Environ. 239: 376-384.

Milberg P., Bergman K.-O., Jonason D., Karlsson J. \& WesterBERG L. 2019: Land-use history influence the vegetation in coniferous production forests in southern Sweden. - For. Ecol. Manag. 440: 23-30.

Nielsen A. \& Totland Ø. 2014: Structural properties of mutualistic networks withstand habitat degradation while species functional roles might change. - Oikos 123: 323-333.

ОHWAкI A. 2018: How should we view temperate semi-natural grasslands? Insights from butterflies in Japan. - Global Ecol. Conserv. 16: e00482, $12 \mathrm{pp}$.

OHWAKI A., Koyanagi T.F. \& MaEda S. 2018: Evaluating forest clear-cuts as alternative grassland habitats for plants and butterflies. - For. Ecol. Manag. 430: 337-345.

Osborne J.L., Martin A.P., Carreck N.L., Swain J.L., Knight M.E., Goulson D., Hale R.J. \& Sanderson R.A. 2008: Bumblebee flight distances in relation to the forage landscape. $-J$. Anim. Ecol. 77: 406-415.

Palviainen M., Finér L., Mannerkoski J., Piirainen S. \& Starr M. 2005: Responses of ground vegetation species to clearcutting in a boreal forest: aboveground biomass and nutrient contents during the first 7 years. - Ecol. Res. 20: 652-660.

Pengelly C.J. \& CARTAR R.V. 2010: Effects of variable retention logging in the boreal forest on the bumble bee-influenced community, evaluated 8-9 years post-logging. - For. Ecol. Manag. 260: 994-1002.

PotTs S.G. \& Willmer P.A.T. 1997: Abiotic and biotic factors influencing nest-site selection by Halictus rubicundus, a groundnesting halictine bee. - Ecol. Entomol. 22: 319-328.

Potts S.G., Vulliamy B., Roberts S., O’Toole C., Dafni A., Ne'eman G. \& WiLlmer P. 2005: Role of nesting resources in organising diverse bee communities in a Mediterranean landscape. - Ecol. Entomol. 30: 78-85.

Power E.F., JAckson Z. \& Stout J.C. 2016: Organic farming and landscape factors affect abundance and richness of hoverflies (Diptera, Syrphidae) in grasslands. - Insect Conserv. Divers. 9: $244-253$.

Proctor E., Nol E., Burke D. \& Crins W.J. 2012: Responses of insect pollinators and understory plants to silviculture in northern hardwood forests. - Biodiv. Conserv. 21: 1703-1740

Proesmans W., Bonte D., Smagghe G., Meeus I., Decoce G., Spicher F., Kolb A., Lemke I., Diekmann M., BruUn H.H., Wulf M., Van Den Berge S. \& Verheyen K. 2019: Small forest patches as pollinator habitat: oases in an agricultural desert? - Landsc. Ecol. 34: 487-501.

Ram D., Lindström Å., Pettersson L.B. \& Caplat P. 2020: Forest clear-cuts as habitat for farmland birds and butterflies. - For. Ecol. Manag. 473: 118239,9 pp.

Rivers J.W., Galbraith S.M., Cane J.H., Schultz C.B., Ulyshen M.D. \& Kormann U.G. 2018: A review of research needs for pollinators in managed conifer forests. - J. For. 116: 563-572.

Roberts P., King D.I. \& Milam J. 2017: Factors affecting bee communities in forest openings and adjacent mature forest. For. Ecol. Manag. 394: 111-122. 
RodríGuez A. \& KouKI J. 2017: Disturbance-mediated heterogeneity drives pollinator diversity in boreal managed forest ecosystems. - Ecol. Appl. 27: 589-602.

Romey W.L., Ascher J.S., Powell D.A. \& Yanek M. 2007: Impacts of logging on midsummer diversity of native bees (Apoidea) in a northern hardwood forest. - J. Kans. Entomol. Soc. 80: 327-338.

Rubene D., Schroeder M. \& Ranius T. 2015: Diversity patterns of wild bees and wasps in managed boreal forests: effects of spatial structure, local habitat and surrounding landscape. Biol. Conserv. 184: 201-208.

Runborg S. 1994: Historical Maps. Decision Support for Preservation of Nature and Culture in Forestry. Skogsstyrelsen, Rapport 1994: 5, 42 pp. [in Swedish] URL: https://cdn.abicart. com/shop/9098/art96/4645996-abd406-1622-1.pdf.

SAUNDERs M.E. \& LuCK G.W. 2013: Pan trap catches of pollinator insects vary with habitat. - Austr. J. Entomol. 52: 106-113.

Stenbacka F., HJältén J., Hilszczański J., Ball J.P., Gibb H., Johansson T., Pettersson R.B. \& Danell K. 2010: Saproxylic parasitoid (Hymenoptera, Ichneumonoidea) communities in managed boreal forest landscapes. - Insect Conserv. Divers. 3: $114-123$.

SvenNING J.C. 2002: A review of natural vegetation openness in north-western Europe. - Biol. Conserv. 104: 133-148.

Templ B., Mózes E., Templ M., Földesi R., SzirÁk Á., BÁldi A. \& KovÁcs-HostYÁnsZKi A. 2019: Habitat-dependency of transect walk and pan trap methods for bee sampling in farmlands. $-J$. Apicult. Sci. 63: 93-115.

VAN VuURE C. 2005: Retracing the Aurochs: History, Morphology and Ecology of an Extinct Wild ox. Pensoft, Sofia, 431 pp.

Vera F.W.M. 2000: Grazing Ecology and Forest History. CABI, Wallingford, $506 \mathrm{pp}$.
VILJUR M.L. \& TEDER T. 2016: Butterflies take advantage of contemporary forestry: Clear-cuts as temporary grasslands. - For. Ecol. Manag. 376: 118-125.

VilJur M.L. \& Teder T. 2018: Disperse or die: Colonisation of transient open habitats in production forests is only weakly dispersal-limited in butterflies. - Biol. Conserv. 218: 32-40.

Westerberg L., Berglund H.-L., Jonason D. \& Milberg P. 2021: Color pan-traps often catch less when there are more flowers around. - Ecol. Evol. 11: 3830-3840.

Westerfelt P., Widenfalk O., Lindelöw Å., Gustafsson L. \& WESLIEN J. 2015: Nesting of solitary wasps and bees in natural and artificial holes in dead wood in young boreal forest stands. - Insect Conserv. Divers. 8: 493-504.

Westerfelt P., Weslien J. \& Widenfalk O. 2018: Population patterns in relation to food and nesting resource for two cavitynesting bee species in young boreal forest stands. - For. Ecol. Manag. 430: 629-638.

WiLson J.S., Griswold T. \& Messinger O.J. 2008: Sampling bee communities (Hymenoptera: Apiformes) in a desert landscape: are pan traps sufficient? - J. Kans. Entomol. Soc. 81: 288-300.

Wright I.R., RoBERTS S.P. \& Collins B.E. 2015: Evidence of forage distance limitations for small bees (Hymenoptera: Apidae). - Eur. J. Entomol. 112: 303-310.

ŻMinorski M., Berg Å. \& PÄrT T. 2016: Forest clear-cuts as additional habitat for breeding farmland birds in crisis. - Agr. Ecosyst. Environ. 233: 291-297.

Zurbuchen A., Landert L., Klaiber J., Müller A., Hein S. \& DoRn S. 2010: Maximum foraging ranges in solitary bees: only few individuals have the capability to cover long foraging distances. - Biol. Conserv. 143: 669-676.

Received January 28, 2021; revised and accepted April 27, 2021 Published online June 17, 2021 